\section{Studying Hybrids: Sectors and Mechanisms}

\author{
Wolfgang Seibel \\ University of Konstanz, Germany
}

Organization Studies 2015, Vol. 36(6) 697-712 (c) The Author(s) 2015 Reprints and permissions: sagepub.co.uk/journalsPermissions.nav DOI: $10.1177 / 0170840615580005$ www.egosnet.org/os

$@$ SAGE

\begin{abstract}
The present paper introduces and compares two alternative perspectives on hybridity. One is the perspective of hybrids being located at the interface of dominant 'sectors' such as the private for-profit sector, the public sector and the civil society or nonprofit sector. The alternative perspective focuses on a combination of sector-specific governance mechanisms. The paper discusses the characteristics as well as the advantages and disadvantages of those two perspectives and what a combination of both implies for further research with an emphasis on the analysis of organizational pathologies and managerial coping.
\end{abstract}

\title{
Keywords
}

hybridity, managerial coping, mechanism-centred perspective, organizational pathologies, sector-centred perspective

\section{The Puzzle}

Hybrids may be conceived as formal or informal institutional arrangements of overlapping sectoral segments and/or combinations of governance mechanisms. The conventional understanding of hybridity refers to sector-related institutional segments. It pays tribute to the obvious fact that some formal institutions are not exclusively part of the private for-profit sector, the public sector or the civil society/nonprofit sector. A public enterprise is a case in point, as is a tax-exempted foundation active in the art market or a for-profit firm engaged in education under state supervision.

Obvious and clear as it appears, however, such first-hand categorization of institutional arrangements at the overlap of sectoral segments may be misguiding. Classic analyses of social systems and influential contributions to organization theory teach us that formal organizational features and the reality of organizational behaviour may differ substantially. Organizations have their manifest and latent functions (Merton, 1968b [1957]) and they are, thus, subject to unintended or counterintuitive consequences of managerial activities or organizational designs unrelated to manifest sectorspecific attributes. For instance, Philip Selznick in his seminal study TVA [Tennessee Valley Authority] and the Grassroots (1949) analysed how a public agency, behind the smoke screen of reformist ideology, became captured by private interests due to the ostensibly democratic

\section{Corresponding author:}

Wolfgang Seibel, Department of Politics and Public Administration, University of Konstanz, Box 89, Universitätsstrasse 10, Konstanz 78457, Germany.

Email: wolfgang.seibel@uni-konstanz.de 
mechanism of cooptation that in reality undermined the official goals of the agency. Robert Michels (1911) described what he termed 'the iron law of oligarchy' using Germany's pre-World War I Social Democratic Party (SPD) as an illustrative case of counterintuitive hierarchical conditions in a party committed to the ideal of an egalitarian society.

Both of these influential books were studies in hybridity avant la lettre. Selznick described the unintended consequences of the insertion of civil society elements into the realm of public bureaucracy. Michels analysed the emergence of informal hierarchy and bureaucratization in what was supposed to be a participatory civil society organization. What we learn from this is that actual hybridity may originate from informal rather than formal arrangements and that there is good sense in acknowledging the existence of latent hybridities that do not appear on the radar screen when just looking for manifest, formal and official combinations of private, public or civil society-based institutional forms.

On the other hand, overemphasizing informal hybridity and counterintuitive cross-sectoral overlap of governance mechanisms would leave us with an underspecified concept. Somewhere and somehow at a certain point in time any kind of institutional arrangement is subject to divergent stakeholder interests, a variety of latent functions, informal combinations of hierarchical and bargaining-driven mechanisms of coordination or mixtures of selfishness and communitarian stewardship. Defining hybridity too broadly just makes it quasi-ubiquitous and, thus, unidentifiable.

Instead, the present paper advocates a middle-ground approach to a concept-driven analysis of hybridity. On the one hand, studying hybrids should entail not just the study of formal crosssectoral arrangements since that would neglect the role of informal institutional effects and latent combinations of sector-specific governance mechanisms. On the other hand, the 'sectors' have to be taken seriously since they represent not only legally binding institutional arrangements but also broadly acknowledged patterns of legitimate sense making. What made Michel's 'iron law of oligarchy' and Selznick's analysis of cooptation provocative at the time was precisely that their diagnoses did not conform to the official patterns of sense making in the 'sectors' they applied to. Yet, these patterns remained and remain valid as the bottom line of legitimacy and tokens of deliberation about what is right and wrong - which is why a moderate sector-centred perspective on hybrids remains valid as well.

\section{State-of-the-Art Context}

Combinations of a sector-centred and a mechanism-centred perspective on hybrids do exist in the relevant literature but they remained largely implicit. It is helpful to refer to Mario Bunge's statement that thinking in terms of mechanisms implies assuming the existence of systems - read: sectors - of which the mechanisms are part (Bunge, 1997, 2000). In a similar vein, David Billis focuses on what he calls 'principles' as characteristics of the private, the public and the third sector (Billis, 2010, pp. 52-58). The 'principles' in Billis's sense are broadly defined and cover the nature of ownership, the mode of governance, operational priorities, and so on. Most important though is the hint that each sector is characterized by specific principles in support of specific mechanisms of governance. We expect managers in for-profit firms to be committed to the principle of efficiency as a consequence of inter-firm competition, just as we expect appointed officials to be committed to parliamentary legislation that is implemented through the mechanism of hierarchy or nonprofit managers to comply with the principle of volunteerism as a consequence of membership-based participation. Viewed through this angle, the sector-centred perspective on hybrids is an implicit part of a mechanism-centred perspective.

Conversely, the mechanism-centred perspective on hybrids can be interpreted as an implicit part of a sector-centred perspective - which is even more evident in the relevant literature. Oliver E. 
Williamson and the institutional economics school of thought, while referring to inter-firm networks or franchising as illustrative examples, classified as 'hybrids' a combination of 'mechanisms of governance' (Williamson, 1996) such as contractual arrangements combined with hierarchical authority. This is based on the assumption of stable and predictable links between institutional forms and mechanisms that drive human behaviour in a certain institutional setting. Those links are connected to the notion of institutional choice in the sense of comparative advantages of certain mechanisms under certain circumstances such as hierarchy involving lower transaction costs than markets under the requirement of rapid adaptation (Ménard, 2004; Williamson, 1991).

The implicit normative impulse is what the institutional choice school has in common with the literature focusing on the potential improvement of public service provision through third sector elements (cf. Evers \& Laville, 2004; Brandsen, van de Donk, \& Putters, 2006) or the improvement of capitalist managerialism through the promotion of social values supposedly peculiar to the nonprofit sector (Porter \& Kramer, 2006, 2011). Again, what at first glance is a sector-centred perspective does address some sort of mechanism shaping the behaviour of those working and acting in hybrid arrangements. However, while these authors intend to contribute to the efforts to making the world of public bureaucracies and capitalist firms a better place, Billis (2010), Williamson (1991, 1996) and Ménard (2004) address specific segments of organizational performance such as various degrees of accountability and transaction-cost efficiency from the angle of sector-specific comparative advantages.

The present paper, by contrast, addresses hybrids on a merely descriptive basis and with a focus on fluid but sector-specific recombinations of governance mechanisms, such as competition in a hierarchical environment, hierarchy in a competitive environment or participation in a hierarchical environment. In what follows, the prevailing sector-centred perspective on hybrids - their origins, strengths and weaknesses - will be portrayed while the subsequent section gives an outline on the alternative, mechanism-centred perspective in terms of theoretical roots and, again, advantages and disadvantages. The concluding section of the paper addresses implications for further empirical research, emphasizing issues of organizational pathologies and managerial coping.

\section{The Sector-Centred Perspective}

The notion of overlapping sectoral segments and resulting hybrid structures originated from both intellectual endeavour and a changing political environment. The sharp distinction between public and private sector was obviously inappropriate with respect to certain well-established institutional forms such as private enterprises or cooperatives, voluntary associations and foundations. From the late 1970 s on, this led to the notion of a 'third sector' serving, initially, as a residual category for institutional forms that could not be classified as for-profit firms or public agencies.

From here originated an influential strand of scholarly literature that gradually evolved into a positive conceptualization of the 'third sector' or 'non-profit sector' as a response to market failure or government failure or both (Anheier \& Seibel, 1990; Hansmann, 1980; James, 1989; RoseAckerman, 1986; Weisbrod, 1988). It was supplemented by the re-emerging notion of 'civil society' that gained ground in a critical attitude towards government. Both intellectual movements were stimulated by an economic and political environment shaped by the devolution of governmental activity during the 1980s and 1990s that characterized the 'Reaganomics' in the United States and the push to a single European market. While the private for-profit sector was promulgated by liberals and conservatives as the classic alternative to 'big government' and stateregulated core sectors of the economy such as electricity, transportation, telecommunication and state-owned industrial assets, the 'third sector' and the notion of a 'civil society' gained momentum from left-wing or post-materialist scepticism vis-a-vis governmental hierarchy. 
Table I. The sector-centred perspective.

\begin{tabular}{lll}
\hline & Overlapping sectors & Examples \\
\hline 1 & State/private business & State-owned firms, public-private partnerships \\
2 & Private business/civil society & Foundations \\
3 & Civil society/state & Service-providing voluntary associations \\
4 & Civil society/state/private business & Cooperatives \\
\hline
\end{tabular}

These parallel developments had a double impact on the conceptualization of hybrid institutions whose common denominator was the sector-centred perspective. The private sector became the role model in a discourse on public sector reform known as 'New Public Management' which evolved from the early 1990s on. Similarly, the scholarly debates on nonprofit and civil society organizations freed them from their 'relative to the market' and 'relative to government' orientation, evolving into a sector-centred perspective. Nonprofit and civil society organizations gained full recognition not just as neither-nor institutions but as an independent sector distinct from governmental and for-profit organizations. Consequently, this movement of diverging ideological sources but a common reformist thrust was normative and schematic at the same time.

Nonetheless, the sector-centred perspective provides for a more fine-grained categorization than a simple market versus government dichotomy implies at first glance. This is illustrated by the examples in Table 1.

Foundations, for instance, are located at a different zone of overlap than state-owned firms or public-private partnerships. While the state-owned firms and public-private partnerships represent either governmental activity in the business world or business-style behaviour in the public realm, foundations typically combine elite civic participation with capital-mobilizing activity in the business world. Service-providing voluntary associations, by contrast, are based on the mobilization of civic participation as well but usually combine these societal roots with a tax-exempted status and other types of direct or indirect governmental support such as financial subsidies and in-kind support. Cooperatives in the housing or agricultural industry, finally, combine components of civil society, the private business world and the state. On the one hand, cooperatives are part of the associational landscape where membership and grassroot-based decision making matter. On the other hand, they too act in areas where tax exemption and direct or indirect governmental support occur while they are active in a market where they typically compete with private businesses. The list of examples could easily be extended, which indicates the richness of institutional differentiation and the remarkable breadth of classificatory scope already provided by a 'merely' sectorcentred perspective.

\section{Advantages and Limitations of the Sector-Centred Perspective}

One obviously cannot discard the validity of a sector-centred perspective on institutional hybrids. It reflects the main characteristics of dominating formal institutional arrangements in modern societies as long as they are based on free markets and a democratic political system. A sector-centred perspective necessarily puts the emphasis on the legal framework of those formal arrangements. This is of considerable analytical and pragmatic value since the legal status itself reflects essential elements of how societies organize the provision of goods and services and how they mobilize overall acceptance of institutional forms. Thus the sector-centred-perspective is more than just a formal taxonomy since it reflects the manifest patterns of sense making and stabilization required by any type of institutional differentiation. 
However, the limitations of the sector-centred perspective are obvious as well. Emphasizing the formal status of institutional arrangements means not only means neglecting informal variants of hybridity but also neglecting the 'agency' component of institutional differentiation in general. This is not just an abstract insufficiency as far as the classification of real-world institutional arrangements is concerned but, more fundamentally, a serious shortfall when it comes to the analytical specification of the governance effects that are hypothetically linked to the combination of various sector-specific components in a hybrid arrangement. The performance of formal governance structures is based on incentive structures that shape individual human action. What the sector-centred perspective neglects is the very micro-level of human agency where the aggregate effects of the presumed sector-specific organizational behaviour necessarily originate. How and when characteristic elements of market-driven firms do or do not improve the performance of public bureaucracies is dependent on how those elements shape the relevant behaviour of individuals. Whether those elements actually improve organizational performance or just serve as mere symbols that strengthen, at best, the formal legitimacy of governmental agencies can only be determined when focusing on the actual impact on individual or group-related behaviour within the particular organization.

By the same token, the sector-centred perspective turns a blind eye to the actual dynamics of changing institutional arrangements from which, after all, hybrids emerge. It focuses on the endstate of those developments and thus overemphasizes stable and static while neglecting volatile and ephemeral arrangements. Hybrids are presumably not only especially flexible and dynamic due to their composite nature; they also represent an important ingredient of restabilization where formal institutional structures are fragile and ambivalent. Again, the actual management of such hybrid arrangements for the purpose of reintegration and restabilization refers to an agency rather than structure-oriented analytical focus that is clearly beyond the reach of the conventional sectorcentred perspective on institutional hybrids.

A modified variant of the sector-centred perspective that provides a more appropriate avenue to such volatile and ambivalent arrangements and the role of hybridity is the analysis of comparative advantages of sector-specific institutional properties. This is what basically characterizes Williamson's notion of 'discrete structural alternatives' (Willamson, 1991) or Porter's and Kramer's idea to combine the principles of capitalist managerialism and the not-for-profit logic of charity (Porter \& Kramer, 2006, 2011). It includes the idea of decomposability of institutional elements that shape the usual organizational behaviour of standard patterns of sectoral institutional arrangements. When market-driven firms are assumed to compensate, potentially at least, for government failure while government or nonprofit agencies are assumed to compensate potentially for market failure, the implication is that the mutual compensation does not necessarily take place in the form of wholesale replacement. Various sector-specific institutional forms may coexist in one and the same field of service provision or commodity production. Moreover, the very components that make sector-specific institutional forms superior to others may be 'extracted' and transplanted from one institutional mainframe to the other. The notion of selective institutional imitation is actually well-established in the relevant literature (Boxwell, 1994; DiMaggio \& Powell, 1983; McKelvey, 1982). It is here, however, that an alternative perspective emerges, one that is no longer sector-centred but, rather, component or mechanism-centred.

\section{An Alternative: The Mechanism-Centred Perspective}

While the sector-centred perspective on hybrids allows for the notion of recombinant selective sector-specific advantages as a variant of hybridity, the various conceptualizations on which such 'recombinant hybridity' can be based - 'benchmarking', isomorphism, garbage-can patterns, etc. - are 
necessarily underdetermined. Any kind of institutional trait or property may be identified as important for the improvement of institutional performance or the achievement of cohesion and stability. In what follows, a more specific yet less sector-centred perspective will be discussed, which I refer to as mechanism-centred. It is related to Mario Bunge's (2000) notion of 'systemism' as opposed to 'holism' and 'individualism'. While the purely sector-centred perspective on hybrids can be denoted 'holistic' in the sense that it does not establish a hypothetical link between sector-specific properties and presumed incentive structure and behavioural patterns at the individual level, a purely actorcentred perspective that ignores sector-specific linkages between institutional 'structures' and human 'agency' can be characterized as 'individualistic'. As the literature on social mechanisms (Bunge, 1997; Elster, 1989; Hedström \& Swedberg, 1998) emphasizes, individual agency is linked to social structures through system-specific patterns of social coordination.

Those patterns of social coordination are defining elements of sector-specific mechanisms of governance as well. The hierarchy of legal authority is the dominant governance mechanism in the public sector just like competition and exchange are the crucial mechanisms shaping the behaviour of private businesses while participation characterizes civil society organizations. None of these mechanisms appears in its pure form but they comprise the core of social coordination in the respective sector. ${ }^{1}$ The hierarchical governance of the rule of law, the survival of a firm in a competitive environment and the participation of members or clients represent the bottom line of organizational sense making (Weick, 1995, pp. 69-76) in the public, the private and the civil society sector. In this sense, they are sector-specific governance mechanisms. They can be addressed on a taken-for-granted basis but, in an ethnomethodological sense, only in accordance with the 'indexicality' (Garfinkel, 1984 [1967], pp. 4-7) of the relevant sector. Hierarchy and competition are accepted in the public realm and in the business world respectively but they easily become anathema to civil society activists. Conversely, participation of members and clients is a core value in the nonprofit or civil society sector but will be rejected by civil servants committed to the notion of neutrality under the rule of law. Formal hierarchy is part and parcel of business firms but can be challenged on the grounds of survival in a competitive environment as the ultima ratio of managerial performance.

As an alternative to the purely sector-centred perspective on hybridity one may, therefore, conceptualize hybridity as a combination of those basic sector-specific mechanisms (see Table 2).

The obvious advantage of the mechanism-centred perspective is that it facilitates the discovery of latent hybridity. It also facilitates the understanding of the nature of institutional arrangements that usually find themselves at the periphery of scholarly attention precisely because they do not fit the conventional pattern of a sector-centred categorization and/or because they are characterized by behavioral patterns of their main agents that do not conform with the usual stereotypes of how public officials, private business managers or social entrepreneurs in the civil society sector would or should behave.

\section{Competition, rivalry and exchange in a hierarchical environment}

A first example of 'mixed mechanisms' creating the sort of hybridity which a sector-centred perspective tends to ignore are market-specific elements of social coordination in a hierarchical environment. Competition and exchange as market-specific mechanisms do occur in the realm of public agencies where supposedly hierarchical coordination is key. Inter-agency rivalry or exchange in terms of log-rolling or clientelism are necessarily excluded from the official spectrum of 'good governance' and legitimate mechanisms of coordination. Rather, the kind of hybridity represented by a mixture of hierarchy on the one hand and competition and exchange on the other hand is considered an indicator of organizational pathologies. A mechanism-centred perspective not only 
Table 2. The mechanism-centred perspective.

\begin{tabular}{lll}
\hline \multicolumn{2}{l}{$\begin{array}{l}\text { Combination of sector-specific governance } \\
\text { mechanisms }\end{array}$} & Examples \\
\hline I $\quad \begin{array}{l}\text { Competition and exchange/reciprocity in a } \\
\text { hierarchical environment }\end{array}$ & $\begin{array}{l}\text { 'bureaucratic politics' (Allison \& Halperin, 1972); } \\
\text { occupation regimes; colonialism } \\
\text { Markets for charity; successfully failing (I)NGOs } \\
\text { Competition/rivalry in a participa-tory/ } \\
\text { grassroot environment } \\
\text { Hierarchy/authority/coercion in a competitive } \\
\text { environment }\end{array}$ & Trusts; oligopolies; hegemony; 'soft power' \\
$4 \begin{array}{l}\text { Hierarchy/authority/coercion in a participatory/ } \\
\text { grassroot environment } \\
\text { Participation/grassroot involvement in a } \\
\text { hierarchical environment } \\
\text { Participation/grassroot involvement in a } \\
\text { competitive environment }\end{array}$ & $\begin{array}{l}\text { Oligarchy in grassroot organizations (Michels, } \\
\text { 19II) } \\
\text { Co-optation in public bureaucracy (Selznick, } \\
\text { 1949); participatory leadership } \\
\text { Corporate citizenship; diversity management; } \\
\text { co-opted consumerism }\end{array}$ \\
\hline
\end{tabular}

serves best the purpose of describing those unusual and illegitimate types of hybridity but also the purpose of identifying the reasons why those pathological forms of organizational behaviour do occur and persist.

Competition and rivalry among various departments and agencies in a public bureaucracy provide a case in point. It is a market-type behaviour that deviates from the core of bureaucratic identity building based on the notion of 'rule of law', public service or loyal stewardship - but at the same time is the consequence of the very goal-oriented, thus active, managerial leadership that is a necessary ingredient of high performance civil service. Committed bureaucrats may take on various roles (see Downs, 1967), one of which is being an ardent proponent of the respective department's or authority's cause. ${ }^{2}$ Interdepartmental and inter-agency competition is the inevitable consequence. To what extent does such market-type behaviour have a similar performance-improving effect as competition supposedly has on a free commodity market, and to what extent does it result in self-paralysing internal conflict, goal deflection in the form of 'bureaucratic politics' (Allison \& Halperin, 1972) or even 'bureaucratic sabotage' (Brecht, 1937), are open empirical questions. What is certain, however, is that interdepartmental and inter-agency competition and rivalry within the hierarchical environment of public bureaucracies represent a latent type of hybridity that results in manifest leadership challenges. One basic decision to be taken by leading staff members is, for example, whether to acknowledge or even to encourage interdepartmental and inter-agency rivalry and competition for the sake of innovation and improved performance, or to suppress or at least neutralize it as illegitimate and detrimental to the common cause of public service. Skilful leaders may also try to strike a balance between these options or to apply both of them selectively on various occasions, in various areas or at various points in time. Whatever the chosen strategy, it will require a sound understanding of the hybrid nature of the relevant overlapping governance mechanisms in the first place.

The relevance of appropriate intellectual grasp and related leadership skills is salient in yet another case of market-type behavioral patterns in a hierarchical environment, that is, in regimes of occupation and colonialism. Obviously, the conventional assumption here is that the dominant governance mechanism is rigid hierarchy. Yet both empirical evidence and theoretical consideration tell otherwise. For the sake of persistence and stability, colonial rule and occupation regimes need to strike a balance between hierarchy and reciprocity as relevant governance mechanisms. Somehow and to various degrees domestic interests and their political or societal representatives need to be 
satisfied in order to achieve the loyalty and thus stability of the dominant hierarchical order as such (Eckert, 2007; Lammers, 1988; De Wever, VanGothen, \& Wouters, 2006). The same holds for the stability of empires and hegemony in general (Mann, 1986, pp. 130-178; Triepel, 1961 [1899]; Lundestad, 1998). The basic reason is that reliance on hierarchical governance entails the risk of 'imperial overstretch' (Kennedy, 1989) in terms of control costs while at the same time encouraging passive or open resistance. While it is clear that hierarchy including the use of force remains the basic governance mechanism, enduring stability of colonial and occupation regimes is based on the mutual dependency of the rulers and the ruled and, thus, reciprocity and exchange. And it also becomes apparent that the acknowledgement of that hybridity and the way it is being handled is a question of intellectual capacity, political judgement, managerial skills and political entrepreneurship (see Lugard, 1965 [1922], for a first-hand description of British indirect rule in Tanzania).

\section{Competition and rivalry in a participatory environment}

Participation can be characterized as the dominant governance mechanism in the civil society sector. It is the very ethos of civil society organizations that individuals engage in collective action for a common cause, a collective good or the public interest. Yet these initiatives may also be driven by market-type competition and rivalry as is the case with the aforementioned market-type governance mechanisms within the hierarchical environment of public bureaucracies, colonial rule and occupation regimes. Again, one reason is the particular resource dependency that shapes the behaviour of civil society organizations beyond their official philosophy of participation and grassroot initiative. Civil society organizations do need resources, financial resources in particular, but due to their very nature as 'neither-state-nor-business' institutions they typically cannot mobilize resources through public budgets or profit-making activity. They have to struggle for market shares and for access to social capital that in turn enables them to mobilize financial resources.

As a consequence, there is a struggle for market shares where civil society organizations in the form of nonprofit organizations, nongovernmental and international nongovernmental organizations compete with each other for contracts. This takes place at both the international or transnational and the national level. NPOs and NGOs may compete for social service contracts and/or the role of a recognized representative of civil society purposes such as human rights protection or development aid. They will try to mobilize and/or to establish interpersonal networks that give access to social capital for the purpose of fundraising and donation campaigns. In doing so, they will necessarily behave like market-driven entrepreneurs and they have to pay tribute to the societal elite structures that represent the opposite of the participatory principles to which they are committed.

So this kind of hybridity necessarily leads to frictions between diverging governance mechanisms which NPOs and NGOs are either unaware of or unwilling to acknowledge. Some of those frictions even result in perverse effects that contradict the official purpose and the basic principles of NPOs and NGOs. Being dependent on a market share in charity or advocacy means to be implicitly interested in the persistence of the problems which the relevant NPO or NGO is designed to solve. What is more, the logic of reciprocity that applies to the mobilization of social capital for the sake of fundraising and donation campaigns may undermine the goal-oriented performance of NPOs and NGOs. Board members recruited due to their personal reputation and as representatives of elite networks gain additional reputation and additional access to further networks in return. What emerges is a logic of exchange that is independent of the NPO's or NGO's performance. On the contrary, high performance NPO and NGO managers may get into trouble when trying to make the organization independent from the type of volatile resource mobilization that is being realized through influential board members. Thus high performance managers and influential board members do not necessarily work smoothly together, with the leverage of professional managers 
shrinking to the extent to which the organization maintains its close linkages to elite networks through board membership for the sake of mobilizing monetary and reputational gains. So, ironically, NPO and NGO success and long-lasting stability may be dependent on low performance and failure (Seibel, 1996).

\section{Hierarchy, authority and coercion in a competitive environment}

The private for-profit sector in a free market economy is the epitome of a competitive environment in the classic liberal sense described by authors such as Joseph Schumpeter (1939) and Friedrich A. Hayek (1944). Ronald Coase's (1937) and Oliver A. Williamson's (1975) discovery was that hierarchal coordination in the form of organized business is not only a necessary evil in a marketdriven contractual setting but a valid alternative to the 'horizontal' market type of governance as soon as hierarchical coordination reduces transaction costs. Beyond that particular recognition of hierarchy in a world of markets and competition, however, manifold phenomena of latent hierarchy remain unacknowledged or, when acknowledged, are defined as an atypical deviation. Trusts and oligopolies are examples from the business world while hegemony or cultural dominance are examples from the political world.

Universities provide a salient example for an informal yet implicitly recognized mixture of competition and hierarchy as mechanisms of social coordination. The shared ethos of scholarly research is that any original idea counts. No social hierarchy should spoil the development and dissemination of research results. Teamwork as an essential part of research entailing division of labour research is supposed to be based on the free competition of ideas regardless of the social or professional status of the authors. The double-blind anonymous referee system of scientific journals reflects that logic of pure competition in a free market of scholarly ideas and innovation.

However, the reality of scholarly production tells otherwise. As Robert K. Merton pointed out in a famous paper on 'The Matthew Effect in Science' (Merton, 1968a), science as a social institution entails a substantial degree of latent hierarchy. Prominent academics are exponentially more frequently quoted than less prominent scholars regardless of the relative degree of innovation in their books and articles. Often, their work is quoted regardless of whether it is relevant for the specific research problem at hand. It is also a common experience in a scholar's social life that reputational hierarchy and formal rank influence the probability that ideas put forward in papers and discussions are picked up by other participants.

It comes with the nature of hybridity that the latent hierarchies within a competitive environment cannnot be openly addressed without causing controversies, irritations or denial. In practice, those at the upper levels of the latent hierarchy in the scholarly world will show no inclination to change the status quo, while those at the lower levels will not easily dare to address the issue - not so much out of fear of sanctions but out of fear of being perceived as not fit enough for survival in a tough environment where the undesirable effects of both competition and hierarchy complement each other.

\section{Hierarchy, authority and coercion in a participatory environment}

Participation in the actual provision of goods and services is the dominant governance mechanism in the civil society sector. It is the 'grassroot' philosophy that distinguishes civil society organizations from private businesses and public sector administration. This is also a defining component of civil society activists' self-perception. Identity building in civil society organizations entails strong anti-hierarchical elements. In the self-perception of activists, civil society organizations are 'democratic' to the extent that they avoid hierarchy and formal authority. Frictions may arise when mere functional necessities require the appointment of chairpersons, for instance for the sake of 
securing accountability or just in accordance with legal requirements. From this it follows that, to some extent, civil society organizations cannot avoid structural hybridity in the sense of overlapping participatory and hierarchical governance mechanisms.

As mentioned in the introductory section of this paper, Robert Michels in his book on sociology of political parties (1911) stated that latent hierarchy in the form of oligarchical power structures is an inescapable phenomenon even in left-wing political parties whose agenda is strictly democratic and anti-hierarchical. He pointed to a contradictory arrangement which today still shapes the nature of civil society organizations, namely, the gap between its identity-building ideology on the one hand and organizational reality on the other hand. Civil society initiatives may turn into organizations in denial of their own existence. As Michels pointed out, organization means management and management implies hierarchy. However, when hierarchy is rejected for ideological reasons while being required by functional necessity, its actual emergence and impact will remain unchecked. In the extreme case such as in totalitarian movements and parties, the participatory philosophy is reduced to a hollow shell that conceals pure authoritarianism. ${ }^{3}$ But within the conventional range of organizational behaviour it is rather the hybridity of participatory and hierarchical governance mechanisms that shape the reality of civil society organizations.

\section{Participation and grassroot involvement in a hierarchical environment}

The hierarchical rule of the law and its organizational consequences - the formal authority of lawabiding civil service organizations - form the dominant governance mechanism in the public sector. However, the extensive literature on governance in the public sector (see Kooiman, 2003, as an exemplary contribution) has made us aware of the relativity of that dominance. So the competing logic of participation and grassroot involvement is widespread if not ubiquitous in the public realm. This is partly due to the general necessity to secure stewardship and commitment among rankand-file civil servants. 'Participatory leadership' is as present or absent in public bureaucracies as it is in private businesses. However, the notion itself can be regarded as an oxymoron indicating the hybridity of the phenomenon in question. Participatory leadership is supposed not to affect one of the crucial virtues of hierarchy which is securing responsibility and accountability. In reality, however, participation of staff members may serve as a pretext for avoiding the assumption of personal responsibility. Enhancing the desired motivational effects of participation and avoiding the undesirable consequences of diluted responsibility and accountability is exactly where hybridity turns into managerial challenges that need to be met for both pragmatic and normative reasons.

While participatory leadership is an example of internal hybridity when it comes to overlapping governance mechanisms, important sources of participatory activity in the hierarchical environment of public bureaucracies reside outside the boundaries of public agencies themselves. One of those sources is the influence of stakeholders such as clients or interest groups. Consider again Philip Selznick's classic TVA and the Grass Roots (1949) as an account of a crucial coping strategy which he termed co-optation. Influential stakeholders outside a public agency can be integrated into the hierarchical structure of the agency by giving them a say within the organization's governance structure, for example, through co-opting them onto the agency's board. Selznick also analysed what might be the price to be paid for such an integration strategy, namely, deviation from the initial goals of the agency concerned, at the expense of parliamentary responsibility and control. There is no doubt, however, that in principle participation by means of co-optation and regular bureaucratic hierarchy may form a functionally well-adapted type of overlapping, thus hybrid, governance mechanism.

Another variant of making the hierarchical structure of public bureaucracy more responsive to outside participation is what Donald Kingsley (1944) termed 'representative bureaucracy'. Kingsley pointed to the fact that the responsiveness of democratic bureaucracy cannot be separated 
from the group-related composition of the staff. Overrepresentation or underrepresentation of particular societal groups within the rank-and-file body of public administration may create risks for both legitimacy and performance. This is obvious in the case of social services, for example, faceto-face contact in ethnic communities, the appointment of top-ranking officials or the composition of governing boards of public agencies. But it is also clear that controlled representation of societal groups within the body of the personnel of public agencies may collide with the unfettered implementation of the legal purpose of a given agency - thus the enforcement of formal hierarchy - since that purpose necessarily treats the internal social structure of public bureaucracy as a neutral 'black box' (Seibel, 2010). It is here that the hybrid character of two overlapping governance mechanisms, hierarchy and participation/representation, comes to the fore.

\section{Participation and grassroot involvement in a competitive environment}

Competition among producers of commodities and providers of services is the dominant governance mechanism in the private for-profit sector. However, not only do we find hierarchy and formal authority as an integral element in the world of private businesses but also civic engagement and a kind of grassroot involvement as a complement or even supportive element of competitive corporate behaviour.

Private businesses pay tribute to societal values and aspirations both in terms of image management and marketing strategies. Much of what prominent authors promulgate as the virtue of hybridity when it comes to social values in business life (Porter \& Kramer 2006, 2011) is already well established in reality. 'Corporate citizenship' in the form of supporting local welfare institutions, sponsoring private or public initiatives in the arts, education or sports, ostentatious commitment to elevated labour standards, promoting and heralding staff diversity and similar measures reflect a firm's societal embeddedness as a diffuse frame of reference that is actively addressed in an attempt to polish a firm's image (Matten \& Crane, 2005). Moreover, firms may use existing activities of consumerism to make their own marketing strategies more closely aligned with what the consumer really wants. Energy-saving household items or organic foods represent fields where active consumerism and skilful marketing of producers form an implicit alliance to mutual benefit. Articulated consumerism as a participatory societal movement may work in the interest of profit-making firms just as the existence of competitive firms that address the demanded commodities of a certain quality or origin strengthens the position of the respective consumerism movement. The hybrid character of the arrangement is revealed by the fact that under the aforementioned conditions managers cannot afford to develop competitive marketing strategies without explicitly or implicitly consulting the relevant segment of articulated consumerism.

\section{Advantages and Limitations of the Mechanism-Centred Perspective}

The significant advantage of the mechanism-centred perspective is the emphasis on latent hybridity. With the help of the mechanism-centred perspective we discover hybrids where we would not necessarily expect them. Mutual dependency and reciprocity between foreign powers and domestic actors in a colonial regime or occupation administration are counterintuitive phenomena, as as rivalry, competition and turf wars among public agencies. The same holds for implicit hierarchy or authoritarianism as a complement to the participatory philosophy of nonprofit and nongovernmental organizations. Also, the fact that public agencies may be much more inclined to adopt a participatory logic in favour of local interests even at the expenses of impartiality and efficient performance is much better understood when analysed through a perspective that focuses on actual mechanisms 
of social coordination and related incentive structures for individual agency than on the explicit overlap of different institutional sectors. By the same token, the mechanism-centred perspective is better equipped to depict dynamic rather than static hybridities since it emphasizes the overlapping nature and interaction of diverging and/or mutually complementary mechanisms of social coordination without a fixed institutional end-state.

However, some limitations of the mechanism-centred perspective are obvious as well. Overemphasizing the flexible and recombinant nature of overlapping governance mechanisms may lead to concept stretching in the sense that hybridity is defined as a ubiquitous, de-institutionalized phenomenon. Somehow under certain circumstances in a broad variety of institutional arrangements, governance mechanisms always overlap. Accordingly, overemphasizing the informal while neglecting formal arrangements in an attempt to discover pure mechanisms that create hybridity may leave us with just basic truisms of social analysis in the vein of structural-functionalism, which is that social structures entail a broad variety of latent functions (Merton, 1968b [1957]) and that it is precisely the fact that they cannot be specified in advance which makes them a peculiar subject of social research.

At the same time, however, structural-functionalism gives some hints on how to avoid the shortcomings of under-specification. What Merton's distinction between manifest and latent functions and Bunge's 'systemism' (Bunge, 2000) have in common is the prioritization of certain functions (Merton) and mechanisms (Bunge) over others. Just as it is obvious that the prime mechanism that drives a school is learning and the prime task of a store is trade, so it is obvious that the prime and manifest mechanisms in the public sector, the private sector and civil society differ and that they differ systematically. This is why focusing on the sector-specificity of dominant or manifest governance mechanisms and their overlap or combination appears to be the most promising approach to the study of hybrids.

\section{Conclusion: Implications for the Analysis of Organizational Pathologies and Managerial Coping}

Ideally, the middle-ground approach advocated for in the present paper should combine the advantages of the sector-centred and the mechanism-centred perspectives. Detecting latent hybridity is what the mechanism-centred perspective makes possible, while the sector-centred perspective enables us to limit the range of hypothetically relevant mechanisms. This has a double implication in terms of promising research questions and research designs, one structure-related and one agency-related.

In terms of structural analysis, one issue of obvious importance is the potential of latent hybridity to turn into organizational pathologies. It comes with the nature of latency that its consequences are hard to control (Merton, 1996 [1936]). However, the sector-centred element of a middle-ground approach to the study of hybrids makes it possible to set a sharper focus on the convergence of sector-based governance mechanisms and the specific pathologies that may result from them. Under what circumstances do participatory elements in the realm of public sector service provision turn into clientelism and/or agency capture? How productive or counterproductive is latent hierarchy in organizations and communities committed to equal rights and equal access to resources, including power and information sharing, such as the world of science or arrangements of regional integration in world politics? When and how does inter-agency competition within the supposedly seamless hierarchy of accountability of the public sector turn into organized irresponsibility? When and how does inter-agency competition in the nonprofit sector stimulate nongovernmental organizations to reduce their efforts to solve problems on whose persistence depends their own funding through state agencies or intergovernmental organizations? The series of questions can easily be expanded on the basis of the above outline on potential types of hybridization of sector-related governance mechanisms. 
The agency-related implication refers to the actual coping strategies in use when the frictions and contradictions of hybridity come to bear in the form of managerial dilemmas. Selling the idea of competitiveness in a participatory environment or advocating client participation and reciprocity in a hierarchical environment requires tactical and communication skills that may decisively contribute to the viability of hybrids.

In accordance with research on diversity and faultline management (Lau \& Murnighan, 1998; Hambrick, Li, Xin, \& Tsui, 2001; Thatcher, Jehn, \& Zanutto, 2003) one may hypothesize that both communication in the form of framing and reframing organizational issues (Jason, 2011; Stanovich \& West, 1998; Vliegenthart \& van Zoonen, 2011) and coalition building based on specific incentive structures play an important role in managing hybrids. 'The heart of all controlled strategy development is coalition management,' Quinn and Voyer argue, and 'top managers act at the confluence of pressures from all stakeholders. These stakeholders will form coalitions, so managers must be active in forming their own' (Quinn \& Voyer, 1998, p. 110).

For instance, while it is plausible to ask for a redefinition of productivity in a for-profit firm through the insertion of social values usually akin to the nonprofit sector (Porter \& Kramer, 2011) the actual managerial challenge is to define the required framing strategy in an attempt to address both the perception patterns of top managers and the investment interests of shareholders. Successfully coping with that challenge very much depends on whether the claim that enhanced value chains also enhance the ultimate viability of a firm is credible in the perception of those two groups - which obviously cannot be taken for granted. It is an open question whether and how responsible managers achieve that credibility by means of mere communication or by forging new coalitions based on selective incentives for various groups.

Framing strategies and coalition building will also influence the outcome of managerial efforts to enhance market-style competitiveness and accountability in nonprofit organizations. Whether those elements are being communicated and perceived as indispensible ingredients of improved performance in the interest of the clientele or as instruments of capitalist managerialism alien to a civil society-based nonprofit organization again depends on appropriate framing, while the readiness and energy with which tentative frames are used and accepted depends on the incentive structure for coalition building among various groups within the organization.

Board members of nonprofit organizations, for instance, may perceive the introduction of market-style managerial components as a prerequisite for organizational survival. This should make them the natural allies of entrepreneurial NPO managers. By the same token, however, NPO board members may perceive market-style managerial efforts as a threat to their own influence and power since they strengthen the position of NPO managers. In that case, board members may seek alliances with paid staff and volunteers while using communicative frames that denounce the respective managerial reforms as inappropriate in a nonprofit environment.

So what we gain from a middle-ground approach to the study of hybrids that combines the relative strengths of the sector-centred and the mechanism-centred perspective is a theoretical lens focused on potential organizational pathologies and a limited scope of potential challenges of rival norms and incentives and related coping strategies. Moreover, the distinction of manifest (sectorbased) and latent (mechanism-based) hybridity also implies awareness of the limits of conscious strategy building in a hybrid environment in general. Manifest hybridity in the form of a public enterprise, a nonprofit organization or a for-profit firm engaged in education under state regulation is hard to imagine without some sort of articulated understanding of the managerial challenges connected to the special position at the interface of various sectors. Whether the definitions of the challenges are appropriate or not is a different question. By contrast, it comes with the nature of latent hybridity that it may persist behind a veil of ignorance. If heroic assumptions about active and conscious management of diverging norms and interests in a hybrid environment - including 
those outlined above - hold true or if hybrids survive as problem nonsolvers (Seibel, 1989, 1996) whose faultlines are successfully ignored, is yet another empirical question.

\section{Acknowledgements}

I am indebted to Gorgi Krlev and two anonymous reviewers for valuable comments on an earlier version of this paper as well as to Angelika König who took care of the formal streamlining in accordance with the OS house style.

\section{Funding}

This research received no specific grant from any funding agency in the public, commercial, or not-for-profit sectors.

\section{Notes}

1. This comes close to what in a recently renewed strand of literature has been identified as institutional logics and the institutional contradictions connected with them (cf. Thornton, Ocasio, \& Lounsbury, 2012). In a seminal article of 1991, Friedland and Alford maintained that core institutions of modern society such as the capitalist market, the bureaucratic state, democracy, family and so on shape individual preferences in accordance with a specific logic (such as accumulation and commodification of human activity as the central logic of capitalism, rationalization and regulation of human activity by legal and bureaucratic hierarchies as the logic of the state, or participation and the extension of popular control as the logic of democracy) and that, in a certain organizational setting, these logics may overlap and contradict each other (Friedland \& Alford, 1991, especially pp. 256-259). In a similar vein, Hedström and Swedberg, in the introductory chapter to their basic volume on social mechanisms, point to the potential overlap and counteraction of mechanisms (Hedström \& Swedberg, 1998, pp. 21-23). However, while 'institutional logic' primarily refers to the structural aspect shaping individual behaviour (cf. Leca \& Naccache, 2006), the notion of sector-specific 'mechanisms' provides us with a more appropriate metaphor when it comes to the interactive aspects of structure and agency.

2. Downs (1967, pp. 92-111) calls the prudent protagonists of departmental interests 'advocates' as opposed to 'zealots' who just pursue a narrow-minded agenda. The affinity to Niskanen's (1971) theorem of the budget-maximizing bureaucrat is obvious but Downs' concept of various role patterns is a more finegrained portrayal of actual bureaucratic behaviour.

3. The irony is that Michels, a disciple of Max Weber, became a proponent of political authoritarianism in the form of Italian fascism in the 1920s (see Nye, 1977).

\section{References}

Allison, G. T., \& Halperin, M. H. (1972). Bureaucratic politics: A paradigm and some policy implications. World Politics, 24, 40-79.

Anheier, H. K., \& Seibel, W. (1990). The third sector: comparative studies of nonprofit organizations. Berlin: De Gruyter.

Billis, D. (2010). Towards a theory of hybrid organizations. In D. Billis, Hybrid oganizations and the third sector (pp. 46-69). Basingstoke: Palgrave Macmillan.

Boxwell, R. J. (1994). Benchmarking for competitive advantage. New York: McGraw-Hill.

Brandsen, T., van de Donk, W., \& Putters, K. (2005). Griffins or chameleons? Hybridity as a permanent and inevitable charateristic of the third sector. International Journal of Public Administration, 28, 749-766.

Brecht, A. (1937). Bureaucratic sabotage. Annals of the American Academy of Political and Social Science, 189(1), 48-57.

Bunge, M. (1997). Mechanism and explanation. Philosophy of the Social Sciences, 27(4), 410-465.

Bunge, M. (2000). Systemism: The alternative to individualism and holism. Journal of Socio-Economics, 29(2), 147-157. 
Coase, R. H. (1937). The nature of the firm. Economica, 4, 386-405.

De Wever, B., VanGothen, H., \& Wouters, N. (Eds.) (2006). Local government in Occupied Europe (1939-1945). Gent: Academia Press.

Downs, A. (1967). Inside bureaucracy. Boston: Little Brown.

DiMaggio, P. J., \& Powell, W. (1983). The iron cage revisited: Institutional isomorphism and collective rationality in organizational fields. American Sociological Review, 48, 147-160.

Eckert, A. (2007). Herrschen und Verwalten. Afrikanische Bürokratien, staatliche Ordnung und Politik in Tanzania, 1920-1970. München: Oldenbourg Verlag.

Elster, J. (1989). Nuts and bolts for the social sciences. Cambridge: Cambridge University Press.

Evers, A., \& Laville, J.-L. (2004). Social services by social enterprises: On the possible contributions of hybrid organizations and a civil society. In A. Evers \& J-L. Laville (Eds.), The third sector in Europe (pp. 237-256). Cheltenham: Edward Elgar.

Friedland, R., \& Alford, R. (1991). Bringing society back in: Symbols, practices, and institutional contradictions. In W. W. Powell \& P. J. DiMaggio (Eds.), The new institutionalism in organizational analysis (pp. 232-263). Chicago: University of Chicago Press.

Garfinkel, H. (1984 [1967]). Studies in ethnomethodology. Englewood Cliffs, NJ: Prentice Hall.

Hambrick, D., Li, J. T., Xin, K., \& Tsui, A. S. (2001). Compositional gaps and downward spirals in international joint venture management groups. Strategic Management Journal, 22, 1033-1053.

Hansmann, H. (1980). The role of nonprofit enterprise. Yale Law Journal, 89, 835-901.

Hayek, F.A. (1944). The road to serfdom. Chicago: University of Chicago Press.

Hedström, P., \& Swedberg, R. (Eds.) (1998). Social mechanisms: an analytical approach to social theory. Cambridge: Cambridge University Press.

James, E. (1989). The nonprofit sector in international perspective: studies in comparative culture and policy. Oxford; New York: Oxford University Press.

Jason, H. (2011). Consent and the problem of framing effects. Ethical Theory and Moral Practice, 14, $517-531$.

Kennedy, P. (1989). The rise and fall of the great powers. New York: Vintage.

Kingsley, D. J. (1944). Representative bureaucracy: an interpretation of the British Civil Service. Yellow Springs, OH: Antioch Press.

Kooiman, J. (2003). Governing and governance. London: SAGE Publications.

Lammers, C. J. (1988). The interorganizational control of an occupied country. Administrative Science Quarterly, 33, 438-457.

Leca, B., \& Naccache, P. (2006). A critical realist approach to institutional entrepreneurship. Organization, $13,627-651$

Lau, D., \& Murnighan, J. K. (1998). Demographic diversity and faultines: The compositional dynamics of organizational groups. Academy of Management Review, 23, 325-340.

Lugard, F. J. D. (1965 [1922]). The dual mandate in British tropical Africa. London: Frank Cass.

Lundestad, G. (1998). Empire by integration: the United States and European integration, 1945-1997. Oxford: Oxford University Press.

Mann, M. (1986). The sources of social power. Volume I: A history of power from the beginning to A.D. 1760. Cambridge; New York: Cambridge University Press.

Matten, D., \& Crane, A. (2005). Corporate citizenship: Toward an extended theoretical conceptualization. Academy of Management Review, 30, 166-179.

McKelvey, B. (1982). Organizational systematics: taxonomy, classification, evolution. Berkeley, CA: University of California Press.

Ménard, C. (2004). The economics of hybrid organizations. Journal of Institutional and Theoretical Economics, 160, 345-376.

Merton, R. K. (1968a). The Matthew Effect in Science. Science, 159, 56-63.

Merton, R. K. (1968b [1957]). Manifest and latent functions. Social theory and social structure (pp. 60-69). Glencoe, IL: Free Press.

Merton, R. K. (1996 [1936]. The unanticipated consequences of social action. On social structure and science (pp. 173-182). Chicago: University of Chicago Press. 
Michels, R. (1911). Zur Soziologie des Parteiwesens in der modernen Demokratie. Untersuchungen über die oligarchischen Tendenzen des Gruppenlebens. Leipzig: Werner Klinkhardt.

Niskanen, W. A. (1971). Bureaucracy and representative government. Chicago: Aldine-Atherton.

Nye, R. A. (1977). The anti-democratic sources of elite theory: Pareto, Mosca, Michels. London: SAGE Publications.

Porter, M. E., \& Kramer, M. R. (2006). Strategy and society: The link between competitive advantage and corporate social responsibility. Harvard Business Review, December, 2-17.

Porter, M. E., \& Kramer, M. R. (2011). Creating shared value: How to reinvent capitalism - and unleash a wave of innovation and growth. Harvard Business Review (Jan-Feb), 2-17.

Quinn, J. B., \& Voyer, J. (1998). Logical incrementalism: Managing strategy formation. In H. Mintzberg, J. B. Quinn, \& S. Goshal (Eds.), The strategy process, revised European edition (pp. 103-110). London: Prentice Hall.

Rose-Ackerman, S. (Ed.) (1986). The economics of nonprofit institutions: studies and structure and policy. Oxford; New York: Oxford University Press.

Schumpeter, J. A. (1939). Business cycles: a theoretical, historical and statistical of the capitalist process. New York: McGraw-Hill.

Seibel, W. (1989). The function of mellow weakness: Nonprofit organizations as problem nonsolvers in Germany. In James, E. (Ed.), The nonprofit sector in international perspective: studies in comparative culture and policy (pp. 178-192). New York; London: Oxford University Press.

Seibel, W. (1996). Successful failure: An alternative view on organizational coping. American Behavioral Scientist, 39, 1011-1024.

Seibel, W. (2010). Beyond bureaucracy: Public administration as political integrator and non-Weberian thought in Germany. Public Administration Review, 70, 719-730.

Selznick, P. (1949). TVA and the grass roots: a study in the sociology of formal organization. Berkeley; Los Angeles: University of California Press.

Stanovich, K. E., \& West, R. F. (1998). Individual differences in framing and conjunction effects. Thinking and Reasoning, 4, 289-317.

Thatcher, S. M. B., Jehn, K. A., \& Zanutto, E. (2003). Cracks in diversity research: The effects of faultlines on conflict and performance. Group Decision and Negotiation, 12, 217-241.

Thornton, P. H., Ocasio, W., \& Lounsbury, M. (2012). The institutional logics perspective: a new approach to culture, structure and process. Oxford; New York: Oxford University Press.

Triepel, H. (1961 [1899]). Die Hegemonie: Ein Buch von führenden Staaten. Stuttgart: W. Kohlhammer.

Vliegenthart, R., \& van Zoonen, L. (2011). Power to the frame: Bringing sociology back to frame analysis. European Journal of Communication, 26(2), 101-115.

Weick, K. E. (1995). Sensemaking in organizations. London: SAGE Publications.

Weisbrod, B. (1988). The nonprofit economy. Cambridge, MA: Harvard University Press.

Williamson, O. E. (1975). Markets and hierarchies: analysis and antitrust implications. A study in the economics of internal organization. Glencoe, IL: Free Press.

Williamson, O. E. (1991). Comparative economic organization: The analysis of discrete structural alternatives. Administrative Science Quarterly, 36, 269-296.

Williamson, O. E. (1996). The mechanisms of governance. New York; Oxford: Oxford University Press.

\section{Author biography}

Wolfgang Seibel is Professor of Politics and Public Administration at the University of Konstanz, Germany, and an Adjunct Professor of Public Administration at the Hertie School of Governance, Berlin. His research focuses on the theory and organizational behaviour of public administration, international bureaucracies and hybrid organizations in various forms ranging from occupation regimes during World War II and its impact on the Holocaust to humanitarian intervention and complex UN peacekeeping missions and their linkages to foreign policy. His latest book is Persecution and Rescue: The Politics of the 'Final Solution' in France, 1940-1944 (The University of Michigan Press, 2015). 